\title{
Beyond Comparison? Literary Appropriation and Its Effects on (Post-)Augustan Greco-Roman Text Production
}

\author{
Markus Hafner
}

Institut für Antike an der Karl-Franzens-Universität Graz, Universitätsplatz 3/II, 8010 Graz, Austria https://orcid.org/0000-0003-3578-5517

markus.hafner@uni-graz.at

This article centers, first, on the Roman reception of earlier Greek literature, which is considered less a simple "receiving" offoreign influence and rather an active "taking" and act of appropriation, and, second, on the effects that this process had on Imperial Greek Literature. Thus, it deals with the question whether Greek literature-at least in part-during the Imperial Period can be considered an autonomous, cosmopolitan, and many-centered phenomenon in its own right and impetus, with its independent production centers that constructed and defined their particular identity. Or, alternatively, whether in the Imperial Age up to the second century CE we encounter a dominating perspective in literary texts, which contributed to strengthen and redefine the Roman viewpoint and the center's identity from the periphery. The Greek texts which are discussed in this essay invite the interpretation that the Post-Augustan Age, despite its locally diverse and multiethnical setup, monopolized a perspective, which encouraged the Greek elite to join the Imperial project, thus resulting in a Greco-Roman literature that appears to be beyond comparison.

Keywords: ancient Greek literature / Roman empire / Post-Augustan age / reception / identity / literary appropriation

\section{"The colonized colonizer": Horace's paradoxical statement}

The last work of the Roman poet Horace contains a controversial and paradoxical statement. In the second book of his Epistles (published $11 / 10$ BCE), Horace famously summarizes what Rome owes to the Greeks in terms of literary achievements. In Epistles 2.1.156-157, he concludes that 
Graecia capta ferum victorem cepit et artis / intulit agresti Latio...

Conquered Greece took prisoner her rough conqueror and / introduced the arts to rustic Latium... (trans. Davie)

Horace's verses (cf. Barchiesi, "Roman Perspectives" 103-105) call our attention to the strange fact that the Roman military conquest of the Greek world that took place especially in the third and the second century BCE did not lead to a subsequent Romanization of Greek culturequite the reverse! Contrary to post-colonial assumptions (summarized in Hose, "Post-Colonial Theory" 304-310), which are paradigmatically expressed by William Blake, according to whom "It is not Arts that follow $\&$ attend upon Empire, but Empire that attends upon \& follows The Arts" (quoted by Said 13), in Horace's words the Roman conquerors' cultural landscape became step-by-step Hellenized ever since their first contact with Greek education and learning $(\pi \alpha 1 \delta \varepsilon i ́ \alpha)$. Friedrich Leo thus described the beginnings of Latin Literature as a transfer of culture from the East: "Die Kulturbewegung ist von Osten nach Westen gegangen" (Leo 1). Arts and empire, in other words, went in opposite directions. Horace's statement about Rome's Hellenization evokes the beginnings of Latin literature, founded by half-Greek epic poets such as Livius Andronicus or Ennius, or Cato's (or Naevius') struggle to create a 'Roman identity' through literature. It should be born in mind in this context that already in the fourth and third century BCE Greek historiographers had expanded a Graecocentric view on Rome, the rising power in the west, thus rendering the city-state a part of the Greek world. A late reflex of this incorporation of Rome appears at the end of the first century BCE, when Dionysius from Halicarnassus in his History of Archaic Rome demonstrates that the Romans were originally Greeks, whose city was founded by Arcadian colonists (on which see Gabba). The Republican authors' search for a 'Roman identity' thus appears as a striving for cultural emancipation from the dominating Greek viewpoint. When the perspective changed in later times, the (culturally) colonized people became the new rulers over the former (Rawson 3-18).

\section{The Muse learns to write ... Latin}

The Greek art ('without empire'), which had invaded Rome in the third century, did not lead to Greek dominion over Roman culture. Rather, the beginnings of Roman literature can be considered as an active seizing of Greek culture, i.e. a "translation project," which seemed 
unique in the entire Mediterranean world: "[I]t was by no means nor$\mathrm{mal}$ in the ancient world for conquerors to learn the language of their subjects" (Feeney 30). This literary appropriation was only one aspect of a much broader and longer absorption process of different cultures, which concerned borrowings of material, religious, and linguistic elements. After centuries of competition with other non-Greek, and mostly Italic, ethnicities and peoples such as Etruscans and Samnites, Carthaginians, Celts, Oscans, and Messapi, which led to Rome's hegemony in Italy, the Romans became dominators of the Mediterranean World and appropriated Greek culture step by step (Barchiesi, "Roman Perspectives" 108-109). This process culminated in the first century BCE, when Roman writers had almost completely usurped the literary discourse. According to their views and statements, Ennius (dubbed the "second Homer" [alter Homerus] by Horace, Epist. 2.1.50) and later Virgil had successfully surpassed Homer, and Cicero 'naturalized' Greek philosophy in Rome (Harder 330-353). This spirit of cultural imperialism pervades especially Cicero's late philosophical writings. In an unambiguous passage (Tusculan Disputations 2.5), he calls upon his fellow Romans to attend to the field of Greek philosophy and learning and to appropriate it in order to enrich Latin literature:

hortor omnis, qui tacere id possunt, ut huius quoque generis laudem iam languenti
Graeciae eripiant et transferant in hanc urbem, sicut reliquas omnis, quae quidem
erant expetendae, studio atque industria sua maiores nostri transtulerunt.

Accordingly, I encourage all who are able to do this to grasp distinction in this field also from the now failing hand of Greece and to transfer it to this city, just as our forefathers by their energy and application transferred here all the remaining forms of distinction, at least those that were desirable. (trans. Davie)

As a consequence of such an omnivorous cultural integration process, Roman authors, of both poetry and prose, throughout the first century BCE and the first century CE blended native with alien elements (Walde 26-36), thus creating a heterogeneous material through literary 'Romanization.' Accordingly, Horace's probably ironic statement about Rome being captivated by Greek art, i.e. Rome as the "colonized colonizer" (victor captus), has to be contrasted with the poetic self-definition of the same author some years earlier, in the sealing poem of his three-book collection of Odes (24/23 BCE). In the programmatic Ode 3.30, Horace tells his readers that he has surpassed the Greek lyric poets and has become the classic poet of Augustan Rome, considering 
himself the most eminent importer of Archaic Greek poetry into Latin Literature (3.30.12b-14a):

[...] ex humili potens /

princeps Aeolium carmen ad Italos I

deduxisse modos. [...]

[...] From humble beginnings

I was able to be the first (princeps) to bring Aeolian song

to Italian measures. (trans. West)

In this passage, Horace boasts about having been the first, and finest, poet (princeps) to transfer the Aeolic lyric of Sappho and Alcaeus to Rome, that is, to offer the best lyric in Sapphic or Alcaic stanzas and meters written in Latin so far. This, as I see it, explicit commentary about Horace's own literary appropriation of the Archaic Greek poetic tradition has a deep political connotation, since the word princeps in verse 13 draws a parallel to the emperor Augustus himself. By calling himself a princeps, Horace sets his poetic project in a close relationship with Augustus' cultural enterprise to reinvent all aspects of Roman tradition during his principate. Augustus also motivated Roman authors to carry out a renovation of Latin Literature and to proclaim a new classical Golden Age of Roman arts, which clearly built on the absorption and the integrative use of Greek, particularly Archaic, models (see Connolly 21-42; Mundt). By paralleling his own poetic practice with Augustus' imperial mission, Horace gives a precise statement of Rome's ways of appropriating Greek culture. Thus, whereas Horace's paradoxical statement concerning the Hellenization of Roman culture (Epist. 2.1.156-157) seems to presuppose a rather passive Roman attitude towards the impact of Greek learning, the programmatic passage from his Odes clearly expresses the active taking and overtaking (deduxisse) of literary tradition (on Roman authors' 'appropriating' mechanisms towards predecessors, Greek or Roman, see Hinds; Barchiesi, "Roman Perspectives" 102). In Ode 3.30, in other words, Horace declares his poetic 'principality.' 


\section{Systematizing literary appropriation in the Post-Augustan Age}

The subsequent success of this literary appropriation-at least from the internal Roman perspective-becomes evident in a prominent first century CE text, the literary history, which Quintilianus offers in the tenth book of his monumental Education of the Orator. In his treatise, Quintilianus establishes a comparative history of Greek and Roman authors, whom he combines according to the literary genre, beginning from epic and moving on to other poetic forms (10.1.85, 93, and 105):

Idem nobis per Romanos quoque auctores ordo ducendus est. Itaque ut apud illos Homerus, sic apud nos Vergilius auspicatissimum dederit exordium, omnium eius generis poetarum Graecorum nostrorumque hand dubie proximus. [...] Elegia quoque Graecos provocamus [...] Satura quidem tota nostra est [...]. Oratores vero vel praecipue Latinam eloquentiam parem facere Graecae possunt: nam Ciceronem cuicumque eorum fortiter opposuerim.

I now come to Roman authors, and shall follow the same order in dealing with them. As among Greek authors Homer provided us with the most auspicious opening, so will Virgil among our own. For of all epic poets, Greek and Roman, he, without doubt, most nearly approaches Homer. [...] We also challenge the supremacy of the Greeks in elegy. [...] Satire, on the other hand, is all our own. [...]. But it is our orators, above all, who enable us to match our Roman eloquence against that of Greece. For I would set Cicero against any one of their orators without fear of refutation. (trans. Butler)

According to the professor of Latin oratory Quintilianus, Virgil came very close to Homer, and Latin elegy can easily compete with the Greeks, whereas satire is clearly a Roman invention. Lastly, Cicerowho is Quintilianus' favorite in terms of style and eloquence-holds the position of Rome's magisterial orator and surpasses the best Greeks, even Demosthenes (Ciceronem cuicumque eorum fortiter opposuerim). This syncritical method (De Jonge 300-323), which became very popular in Imperial Times and which is, for example, the ordering principle in Plutarch's Parallel Lives (Erbse 398-424), shows that Quintilianus starts from a clear-cut dichotomy of we (the Romans) versus they (the Greeks). The Romans thus received from the Greeks literary models to emulate and compete with, and except from 'superhuman' Homer, the Romans, according to this statement, put their Greek predecessors in the shade and outdid their literary refinement by appropriating genres, styles, and the art of eloquence. I would even suggest that the alleged comparability, or rather opposition, of both 
Greek and Roman authors in Quintilianus' rewriting of literary history is already a forceful act of appropriation.

Recent scholarship in the field of Roman cultural history has thrown into relief the phenomenon of cultural appropriation, through which Rome-'Empire of Plunder' (Loar, Macdonald, and Padilla Peralta 1-11)—made and remade itself over and over again, in Italy and abroad. It could be shown how such cultural plunder ranged from literary theft to grand-scale spoliation of monuments such as Egyptian obelisks (on the not exclusively Roman phenomenon of 'cultural borrowings' throughout antiquity, see Gruen). However, the effect, which Roman appropriation had on the production of Greek Imperial Literature, and the Greek reaction itself, remain relatively understudied. This leads me to the question whether Imperial Greek Literature in Post-Augustan Times retained its earlier autonomy and impetus due to the impact of Rome's literary appropriation. Scholars have stressed that during the movement of the Second Sophistic (on which see Richter and Johnson 3-9), 'Greekness' and Greek heritage were greater than at any other time, and that Greek identity came before any loyalty to Rome (Swain 17-131). The Imperial Age was, without doubt, pervaded with an ongoing debate on questions of cultural identity (Goldhill 1-25). Accordingly, experts have argued that the Greek elites' many-centered cultural activities during the High Roman Empire (first to third century CE) were based upon the logic to uphold the workings and values of an aristocratic power establishment, in which the exhibition of literary (and, particularly, rhetoric) culture did 'symbolically' reproduce and thus justify the power structure itself (Schmitz 26-31). Others have regarded the production of literature itself as a primary means of asserting the authors' Hellenic identity and of actively constructing their own position vis-a-vis the classical Greek past: "The Hellenism of Greek literature is neither natural nor self-evident - it is rather artfully created." (Whitmarsh, Greek Literature 22; cf. 29-38). The attributes 'Greek' and 'Roman' are thus more and more considered fluid and merging categories, and identity less a static attribution and rather a laborious construction and result of negotiation. However, the allegedly stark contrast, or dichotomy, between Roman power and Hellenic culture and identity in the Eastern Mediterranean, which has motivated comparative approaches on Greek versus Latin Imperial Literature (e.g. Dihle 13-34, 62-74), still informs scholarly views. Many Imperial Greek texts, however, invite an alternative interpretation, fostering a strong impression that there came into existence a relatively coherent bilingual 'Greco-Roman' literature, which was 
strongly directed towards the empire's center: i.e. a literature beyond comparison. Its texts reproduced and redefined Rome's identity from their own peripheral perspective. I shall present and discuss some of the most relevant passages in the sections that follow.

\section{Redefining Rome? Literary production in the Greek periphery}

In the preface to his essay On the Ancient Orators (first century BCE), the Greek teacher of rhetoric, Dionysius of Halicarnassus, who came to Augustan Rome in order to teach members of the Roman upper class, praises the influence that the capital exerts on contemporary literary production, Greek and Latin (pref. 1.2; 3.1):

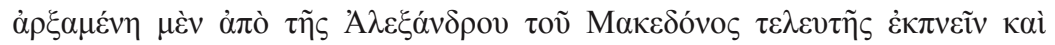

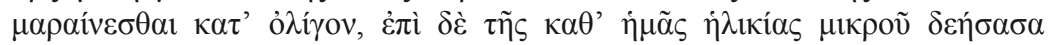

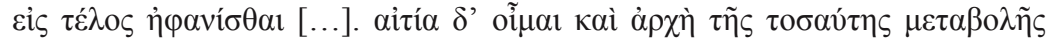

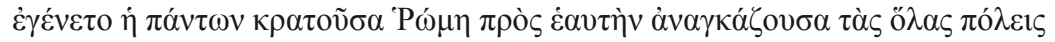

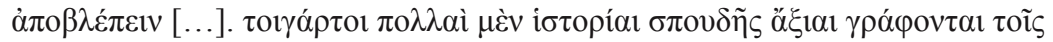

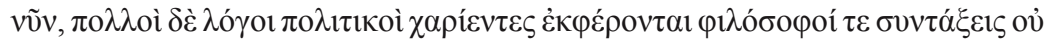

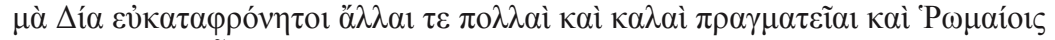

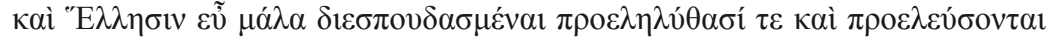

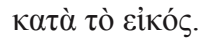

From the death of Alexander [...] [the rhetoric] began to lose its spirit and gradually wither away, and in our generation had reached a state of almost total extinction. [In the following section, Dionysius gives reasons for his view that his own age has shown forth the opposite situation]. I think that the cause and origin of this great revolution has been the conquest of the world by Rome, who has thus made every city focus its entire attention upon her. [...] This state of affairs has led to the composition of many worthwhile works of history by contemporary writers, and the publication of many elegant political tracts and many by no means negligible philosophical treatises; and a host of other fine works, the products of well-directed industry, have proceeded from the pens of both Greeks and Romans, and will probably continue to do so. (trans. Usher)

In this passage, Dionysius links the flourishing of Greek and Latin texts to the renovating power of the Roman Empire, thus confirming to the contemporary Augustan ideology that Rome under his guidance saw a universal renewal of artistic practices (Wiater 60-119). According to this Classicist Three-Period model, a bloom of rhetoric in Classical Athens (fifth and fourth century BCE) led to literary 
(and moral) decadence during the Hellenistic Age after Alexander's death (i.e. from $323 \mathrm{BCE}$ onward). Finally, classicistic tendencies under Roman dominance helped to reestablish rhetoric and literary production in general (Hidber 14-81). Dionysius thus draws parallels between the flourishing Greek empire under Alexander the Great and Augustus' principate of the day, the latter having initiated a new philosophical rhetoric (Wiater 99). As a consequence, it is plausible that the phenomenon of Atticism (Kim 41-53), i.e. the far-reaching establishment of a classicizing style in Imperial Greek literature that was oriented towards fifth and fourth century BCE Athens, developed principally in Rome itself (Hose, "Die zweite Begegnung" 274-288). It was the empire's center where Greek experts and teachers such as Dionysius put together a literary canon to be studied and henceforth to be emulated by their elite Roman disciples. Thus, Dionysius, in his didactic treatise On the Ancient Orators, which addresses students of Greek literature and culture, compares the stylistic particularities of different orators from classical Athens and judges what is worth of imitation ( $\mu$ í $\mu \eta \sigma 1 \varsigma)$, and what is not. Dionysius, who lived and worked in Rome, designed the city as a center of gravity and a literary hotspot which had become responsible for the flourishing and the expansion of (not only Latin, but also) Greek literature and its canon formation during the Augustan period.

\section{Rome as the New Athens?}

In a similar vein, Aelius Aristides, a successful orator from Asia Minor, who visited Rome in the mid-second century CE, considered Rome at least in a metaphorical way - as the true heir of Classical Athens. In his encomiastic speech on behalf of the city of Rome (Klein I 113172), the capital appears as the New Athens on a thematic, but also on a linguistic, level (Regarding Rome, 60-61):

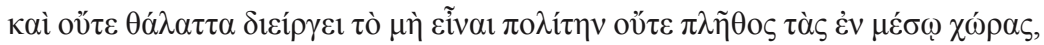

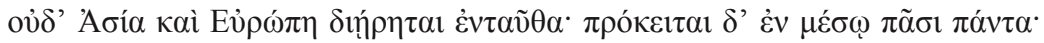

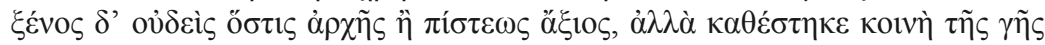

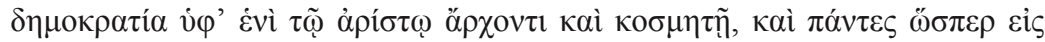

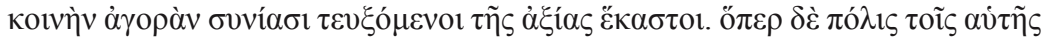

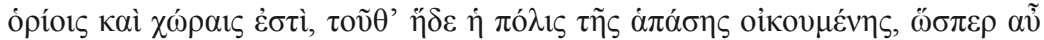

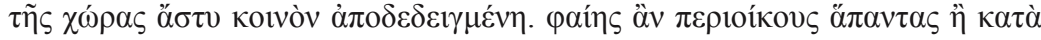

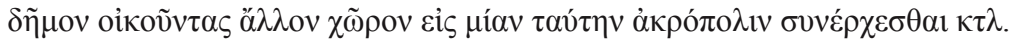


And neither does the sea nor a great expanse of intervening land keep one from being a citizen, nor here are Asia and Europe distinguished. But all lies open to all men. No one is a foreigner who deserves to hold office or to be trusted, but there has been established a common democracy of the world, under one man, the best ruler and director, and all men assemble here as it were at a common meeting place, each to obtain his due. What a city is to its boundaries and its territories, so this city is to the whole inhabited world, as if it had been designated its common town. You would say that all the perioeci or all the people settled in different places deme by deme assemble at this one acropolis... (trans. Behr)

By applying names and institutions, which were highly reminiscent of the Classical Greek City ( $\pi$ ó $\lambda 1 \varsigma$ ), and most concretely of Classical Athens, and by applying keywords such as dèmokratía, agorá, dèmos or akrópolis to Rome itself, Aristides adopts a classicist language denoting an ideal city in generic and traditional terms. The description points to contemporary Imperial Rome, if not to the empire as a whole: "Rome est par conséquent devenue l'acropole de l'univers" (Di Franco 287). This procedure, on the one hand, makes the phenomenon of Rome accessible and comprehensible to the Greek elite audience. Particularly so, since the rhetorical description of the appraised city ("̈ $\pi$ atvo $\pi$ $\pi$ $\lambda \varepsilon \omega \varsigma)$ in Regarding Rome bases on ideological and political assumptions rather than on the exact topography of the Roman landscape ("the City itself is less the material Rome than an idea", Sherwin-White

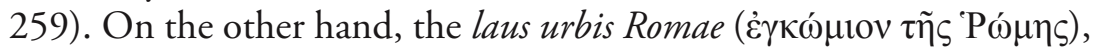
i.e. the praise of the city, mirrors exactly the Roman claim of legitimate succession of Athens (translatio imperii), as well as the appropriation of Greek terms for political and civic achievements. Calling Rome-quite paradoxically (on the semantic shift of the term, see Klein II 89-90)_-

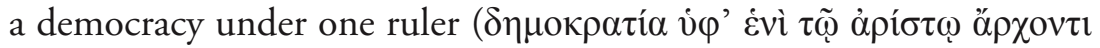
$\kappa \alpha i ̀ ~ \kappa o \sigma \mu \eta \tau \tilde{n ̃), ~ A r i s t i d e s ~ c l e a r l y ~ a l l u d e s ~ t o ~ T h u c y d i d e s ' ~ j u d g e m e n t ~ c o n-~}$ cerning the allegedly democratic, yet actually monarchic rule during

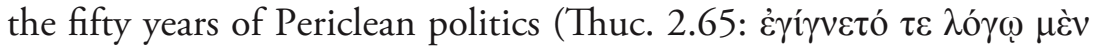

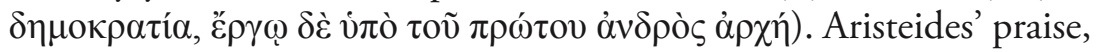
according to which the inhabited and civilized world ( $\dot{\eta}$ oikov $\mu \varepsilon \dot{v} \eta$ ) and the urban center coincide (urbs et orbis), obviously addressed an educated elite of the Greek East and encouraged them to integrate into the new order that appeared as the true heir of Athens (Bleicken 263). Nevertheless, the passage also refers to the global conceptions of Imperial politics and the Roman center's absorption of Greek culture. In the center's perspective, Athens as the capital of Atticism and Greek sophistry played an important role for Imperial Rome's self- 
definition. One might think, for example, of the philhellenic emperor Hadrian, who donated the so-called Athenaeum in Rome, a performance place for sophists, through which Athens, or at least a museumlike version of it, had been attributed a central position for Roman self-definition (Hafner 249-253). That is, even at the core of the vast empire itself culture contacts were negotiated (Barchiesi, "Center and Periphery" 394-405). One might also think of the Hadrian's Arch in Athens (dedicated on occasion of Hadrian's Athenian citizenship and archontate in 111/112 CE), in whose inscription the emperor claimed to be 'refounder' of Athens and a second Theseus (IG II ${ }^{2}$ 5185). Through this arch, which was erected between the old City of Theseus and the new Roman city, the princeps protector placed himself in the tradition of the attic founding-hero. Thus, the 'Hellenization' of the power center and the 'Romanization' of the cultural hotspot of Greece went hand in hand (see Whitmarsh, "Thinking Local" 1-16). Through so-called interpretatio Romana, Rome integrated elements of foreign cultures, leading to a subsequent (and reciprocal) shifting of parameters, which on a local level affected Roman culture as well (see also Hingley). From the overall perspective and despite the increasingly multi-ethnic setup of the empire and its center, the imagination of Rome taking the helm of culture from Greece had become part of a powerful imperialist ideology.

\section{Rome as the structuring principle in history}

Next in our row is the preface of Appianus' Roman History from the middle of the second century CE. The work tries to give an explanation why Rome, whose war campaigns are centered at the core of Appianus' historiographical project, had become the power it was (Hose, Erneuerung 142-355). In originally 24 books, Appianus gave an account of the peoples and territories from the earliest times down to their incorporation into the Imperium Romanum. The preface foreshadows this grand-scale historiographical undertaking (pref. 48-49; 58):

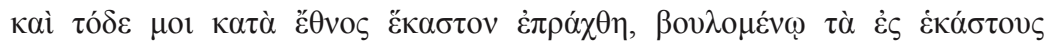

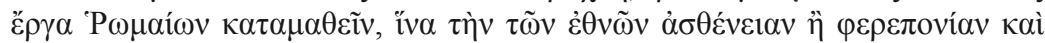

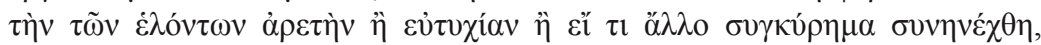

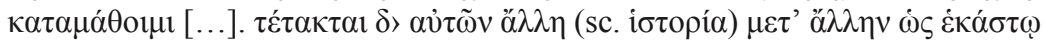

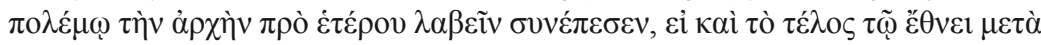
$\pi \mathrm{o} \lambda \lambda \dot{\alpha}$ ह̌ं $\varepsilon \rho \alpha \gamma \varepsilon \gamma \varepsilon \dot{v} \eta \tau \alpha 1$. 
I have made this research also in respect to teach of the other provinces, desiring to learn the Romans' relations to each, in order to understand the weakness of these nations or their power of endurance, as well as the bravery or good fortune of their conquerors or any other circumstance contributing to the result $[\ldots]$. The order of these histories with respect to each other is according to the time when the Romans began to be embroiled in war with each nation, even though many other things intervened before that nation came to its end. (trans. White)

Similarly to the Latin author Florus, who wrote a universal history under Hadrian (Hose, Erneuerung 53-141), which culminated in Rome's domination and the subdued ethnicities' admiratio principis populi (pref. 3), the Alexandrian historiographer arranges his account geographically, by presenting, in a more balanced way than Florus, peoples and territories, the later provinces, in the chronological order, in which they were conquered by the Romans. This narrative technique based itself also on Herodotus, in whose Histories the expansive Persian Empire had been the main ordering principle. Thus, Appianus adapts and updates - apart from other models (Osgood 23-44)-historiographical patterns developed by Herodotus in order to portray the Roman Empire as the structuring principle and the divinely legitimated telos of his narrative project. At the same time, Appianus' Roman History addresses members of the educated provincial elite from the Greek cultural sphere and encourages them to integrate themselves into the Roman monarchy, whose representatives had become more and more interested in modes of collaboration with local elites (Hose, Erneuerung 353-354). By this, the text oscillates and interfaces between center and periphery. For in Appianus' time, the simultaneous strengthening of cultural-ethnic identities and the integrative identity of the Empire were, as Aristides in his Regarding Rome had already anticipated, no exclusive mechanisms any more. However, the almost "kaleidoscopic potential for identity formation realized and yet conduced a singular and peculiarly Roman social order" (Ando 20-21), since the Roman superstructure profited a lot from local entities, such as newly arranged provinces, under its guidance.

\section{Risky undertones}

A few literary voices from Imperial Greek Literature offer a rather pessimistic perspective on the Roman center's monopolization and appropriation of literature. In the following section, I shall focus on the 
epilogue of [Longinus'] treatise On the Sublime (first century CE). The pseudonymous work (Geue 254-271), which is addressed to a Roman upper-class member called Terentianus, leads to a debate on recent developments in the field of rhetoric and literature. As to its complaints on the rhetoric of the day, the epilogue draws parallels with contemporary controversies in Latin Literature (Heldmann 287), such as in Tacitus (cf. Maternus' second speech in the Dialogue on Oratory) or Petronius (Satyricon 1.3-2.8). The author, Pseudo-Longinus, quotes an anonymous philosopher who offers a counter-periodization and an opposite view on current literary history. Taking his magisterial model Homer as a starting point, the anonymous intellectual criticizes the stiff oratory of his time, i.e. the first century $\mathrm{CE}$, which in his view underestimates genius and concentrates only on rhetorical school declamations. Instead of such low-level formalism, the critic focuses on the immediacy of poetic experience of greatness (Sublime 44.1-3):

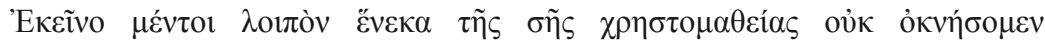

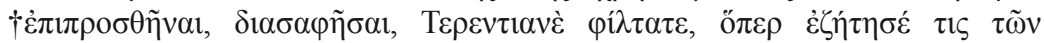

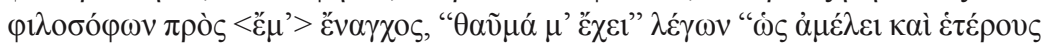

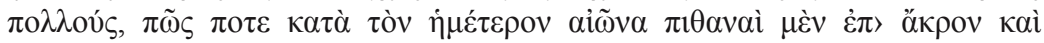

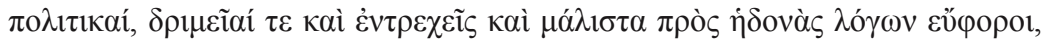

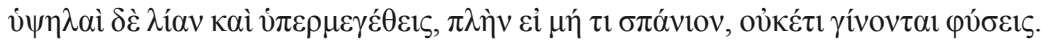

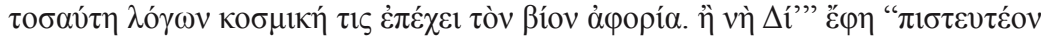

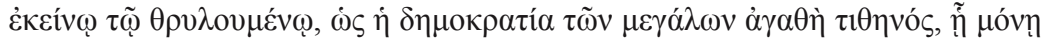

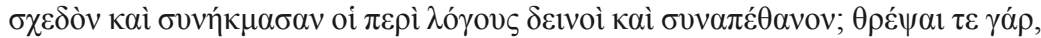

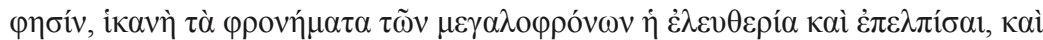

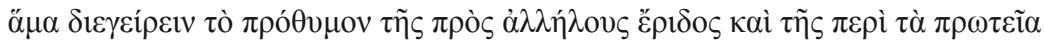

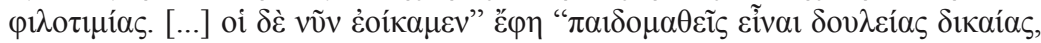

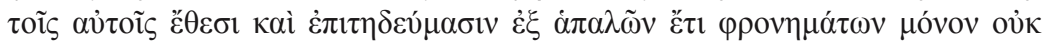

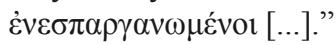

One problem now remains for solution, my dear Terentianus, and knowing your love of learning I will not hesitate to append it - a problem which a certain philosopher recently put to me. "It surprises me", he said, "as it doubtless surprises many others too, how it is that in this age of ours we find natures that are supremely persuasive and suited for public life, shrewd and versatile and especially rich in literary charm, yet really sublime and transcendent natures are no longer, or only very rarely, now produced. Such is the universal dearth of literature that besets our times. Are we really to believe the hackneyed view that democracy is the kindly nurse of genius and that - speaking generallythe great men of letters flourished only with democracy and perished with it? Freedom, they say, has the power to foster noble minds and to fill them with high hopes, and at the same time to rouse our spirit of mutual rivalry and eager competition for the foremost place. [...] But in these days we seem to be 
schooled from childhood in an equitable slavery, swaddled, I might say, from the tender infancy of our minds in the same servile ways and practices. [...] (trans. Fyfe, rev. Russell)

Remarkably, the speaker here links the decline of literature with the change of the political system from Roman Republic to principate. In this, he particularly deplores the loss of freedom in the context of monarchy, which does not produce free thinkers anymore. By linking the decay of intellectual life with the shifting of Rome's political constitution, the anonymous philosopher's critique exhibits a senatorial perspective that is known, e.g., from Cicero's works, in which eloquence appears as a "foster-child of a well-ordered state system", i.e. of the former Roman Republic (Brut. 45 bene constitutae civitatis quasi alumna quaedam eloquentia). In On the Sublime, however, the critic is subsequently refuted by the authoritative voice of the likewise anonymous author (Sublime 44.6). [Longinus] responds to the former speaker that the intellectual decay is by no means a consequence of bad government, but rather due to morally corrupt individuals, thus clearly conforming to the (Post-)Augustan historiographical model.

\section{Conclusion}

The texts that I have discussed in the previous sections of this essay can be put in the context of (Post-)Augustan Rome's project of literary renovation and redefinition. Moving from central to rather peripheral literary voices, I have inferred such an interpretation from Dionysius' treatise On the Ancient Orators, from Aristides' eulogy Regarding Rome, and from Appianus' Roman History, which all reinforce in a more or less direct way a Roman identity, addressing diverse audiences, which were situated throughout, and even on the margins of, the Greek world. Even the complaint about the recently installed Imperial rhetoric in the epilogue of Pseudo-Longinus' On the Sublime, which at first sight forms the exception of the rule, contributes to this identity, since the internal speaker's fierce critique ends up being refuted by the author's voice. The latter clearly conduces to a peculiarly Roman perspective. While many scholars have underscored the autonomous role of Greek Imperial literature as part of a cosmopolitan, connected, many-centered movement of cultural Hellenism in a broad sense, by which a Roman identity was only partly, or superficially, adopted, the texts presented here rather bear witness of Rome's successful strategy of literary appropriation. This regime of 'literary plunder,' so to say, 
which culminated during the omnivorous Augustan classicism and continued to exist during the subsequent centuries $\mathrm{CE}$, had a much more lasting impact on the production of Greek texts than is often realized. Although further conclusions will have to rely on a broader textual base, although the Imperial Age saw a 'kaleidoscopic potential for identity formation' (Ando 20), and although things change abruptly in the third century $\mathrm{CE}$, in the texts discussed here we encounter mostly one overarching perspective. Despite the texts' complexity, it points to the strengthening and redefinition of the center and its identity from the periphery. All this makes me wonder whether we can still sharply contrast different and equally powerful ideological centers in Imperial Times and whether comparison 'between literatures' seems still an appropriate concept regarding an age of all-embracing literary appropriation...

\section{WORKS CITED}

\section{ANCIENT WORKS}

Aelius Aristides. The Complete Works. Vol. II. Speeches xvii-liii. Trans. Charles Behr. Leiden: Brill, 1981.

Appian. Roman History. Vol. I. Trans. Horace White. Cambridge, MA; London: Harvard University Press; Heinemann, 1912.

Cicero. On Life and Death. Trans. John Davie. Ed. Miriam T. Griffin. Oxford: Oxford University Press, 2017.

Dionysius of Halicarnassus. Critical Essays. Vol. I. Trans. Stephen Usher. Cambridge, MA: Harvard University Press, 1974.

Horace. Odes III. Dulce periculum. Text, Translation, and Commentary David West. Oxford: Oxford University Press, 2002.

Horace. Satires and Epistles. Trans. John Davie. Introduction and notes Robert Cowan. Oxford: Oxford University Press, 2011.

Longinus. On the Sublime. Ed. and trans. W. Hamilton Fyfe. Rev. Donald Russell. Cambridge, MA; London: Harvard University Press, 1995.

Quintilian. Institutio Oratoria. Trans. Harold E. Butler. Cambridge, MA; London: Harvard University Press; Heinemann, 1922.

\section{SCHOLARLY LITERATURE}

Ando, Clifford. "Imperial Identities." Local Knowledge and Microidentities in the Imperial Greek World. Greek Culture in the Roman World. Ed. Tim Whitmarsh. Cambridge: Cambridge University Press, 2010. 17-45.

Barchiesi, Alessandro. "Center and Periphery." A Companion to Latin Literature. Ed. Steven Harrison. Oxford: Oxford University Press, 2005. 394-405.

Barchiesi, Alessandro. "Roman Perspectives on the Greeks." The Oxford Handbook of Hellenic Studies. Eds. Barbara Graziosi, Phiroze Vasunia, and George R. BoysStones. Oxford: Oxford University Press, 2009. 98-113. 
Bleicken, Jochen. "Der Preis des Aelius Aristides auf das römische Weltreich (or. 26 K.)." Nachrichten der Akademie der Wissenschaften in Göttingen 7 (1966): 225-277.

Connolly, Joy. "Being Greek/Being Roman: Hellenism and Assimilation in the Roman Empire." Millennium: Jahrbuch zu Kultur und Geschichte des ersten Jahrtausends n. Chr./Yearbook on the Culture and History of the First Millennium C.E. Vol. 4. Eds. Wolfgang Brandes et al. Berlin: De Gruyter, 2004. 21-42.

De Jonge, Casper C. "Demosthenes versus Cicero: Intercultural Competition in Ancient Literary Criticism." Eris vs. Aemulatio. Valuing Competition in Classical Antiquity. Eds. Cynthia Damon and Christoph Pieper. Leiden: Brill, 2018. 300-323.

Di Franco, Matteo. "Dire l'Urbs et l'Empire en grec. La Ville, l'Empire et l'écoumène dans le discours En l'honneur de Rome d'Aelius Aristide." Dire la ville en Grec aux époques antique et byzantine. Eds. Liliane Lopez-Rabatel, Virginie Mathé, and Jean-Charles Moretti. Lyon: MOM éditions, 2020. 283-290.

Dihle, Albrecht. Die griechische und lateinische Literatur der Kaiserzeit. Von Augustus bis Justinian. Munich: Beck, 1989.

Erbse, Hartmut. "Die Bedeutung der Synkrisis in den Parallelbiographien Plutarchs." Hermes 84.4 (1956): 398-424.

Feeney, Denis. Beyond Greek. The Beginnings of Latin Literature. Cambridge, MA: Harvard University Press, 2016.

Gabba, Emilio. Dionysius and the History of Archaic Rome. Berkeley, CA; Los Angeles, CA; Oxford: University of California Press, 1991.

Geue, Tom. Author Unknown. The Power of Anonymity in Ancient Rome. Cambridge, MA; London: Harvard University Press, 2019.

Goldhill, Simon, ed. Being Greek under Rome. Cultural Identity, the Second Sophistic and the Development of Empire. Cambridge: Cambridge University Press, 2001.

Gruen, Erich S., ed. Cultural Borrowings and Ethnic Appropriation in Antiquity. Stuttgart: Steiner, 2005.

Hafner, Markus. "Der 'Mythos Athen' im literarischen Diskursfeld fiktionaler Erzählprosa der Kaiserzeit - am Beispiel von Lukian, Chariton und Heliodor.” Städte und Stadtstaaten zwischen Mythos, Literatur und Politik. Eds. Paolo Cecconi and Christian Tornau, Berlin; Boston: de Gruyter, 2020. 249-268.

Harder, Richard. "Die Einbürgerung der Philosophie in Rom." Die Antike 5 (1929): 291-316 [reprinted in Kleine Schriften. Munich: Beck, 1960. 330-353].

Heldmann, Konrad. Antike Theorien über Entwicklung und Verfall der Redekunst. Munich: Beck, 1982.

Hidber, Thomas. Das klassizistische Manifest des Dionys von Halikarnass. Stuttgart; Leipzig: Teubner, 1996.

Hinds, Stephen. Allusion and Intertext. Dynamics of Appropriation in Roman Poetry. Cambridge: Cambridge University Press, 1998.

Hingley, Richard. Globalizing Roman Culture. Unity, Diversity and Empire. London; New York: Routledge, 2005.

Hose, Martin. Erneuerung der Vergangenheit. Die Historiker im Imperium Romanum von Florus bis Cassius Dio. Stuttgart; Leipzig: Teubner, 1994.

Hose, Martin. "Die zweite Begegnung Roms mit den Griechen, oder: Zu den politischen Ursachen des Attizismus." Rezeption und Identität. Die kulturelle Auseinandersetzung Roms mit Griechenland als europäisches Paradigma. Eds. Gregor Vogt-Spira and Bettina Rommel. Stuttgart: Steiner, 1999. 274-288.

Hose, Martin. "Post-Colonial Theory and Greek Literature in Rome." Greek Roman and Byzantine Studies 40 (2001): 303-326. 
Kim, Lawrence. "Atticism and Asianism." The Oxford Handbook of The Second Sophistic. Eds. Daniel Richter and William A. Johnson. Oxford: Oxford University Press, 2017. 41-66.

Klein, Richard. Die Romrede des Aelius Aristides. Einführung. Darmstadt: Wissenschaftliche Buchgesellschaft, 1981 [= Klein I].

Klein, Richard. Die Romrede des Aelius Aristides. Herausgegeben, übersetzt und mit Erläuterungen versehen von Richard Klein. Darmstadt: Wissenschaftliche Buchgesellschaft, 1983 [= Klein II].

Leo, Friedrich. Geschichte der römischen Literatur. Vol. 1: Die archaische Literatur. Berlin: Weidmann, 1913.

Loar, Matthew P., Carolyn Macdonald, and Dan-El Padilla Peralta, eds. Rome, Empire of Plunder. The Dynamics of Cultural Appropriation. Cambridge: Cambridge University Press, 2018.

Mundt, Felix. Römische Klassik und griechische Lyrik. Transformationen der Archaik in augusteischer Zeit. Munich: Beck, 2018.

Osgood, Josiah. "Breviarium totius imperii: the background of Appian's Roman History." Appian's Roman History: empire and civil war. Ed. Kathryn Welsh. Swansea: Classical Press of Wales, 2015. 23-44.

Rawson, Elizabeth. Intellectual Life in the Late Roman Republic. Baltimore, MD: Johns Hopkins University Press, 1985.

Richter, Daniel and William A. Johnson. The Oxford Handbook of the Second Sophistic. Oxford: Oxford University Press, 2017.

Said, Edward W. Culture and Imperialism. New York: Vintage Books (Random House), 1993.

Schmitz, Thomas. Bildung und Macht. Zur sozialen und politischen Funktion der zweiten Sophistik in der griechischen Welt der Kaiserzeit. Munich: Beck, 1997.

Sherwin-White, Adrian N. The Roman Citizenship. $2^{\text {nd }}$ ed. Oxford: Oxford University Press, 1973.

Swain, Simon. Hellenism and Empire. Language, Classicism, and Power in the Greek World, AD 50-250. Oxford: Oxford University Press, 1996.

Walde, Christine. "Roman Dream Works." Latinitas Perennis. Volume II: Appropriation and Latin Literature. Eds. Wim Verbaal, Yanick Maes, and Jan Papy. Leiden: Brill, 2009. 13-40.

Whitmarsh, Tim. Greek Literature and the Roman Empire. The Politics of Imitation. Oxford: Oxford University Press, 2001.

Whitmarsh, Tim. "Thinking local." Local Knowledge and Microidentities in the Imperial Greek World. Greek Culture in the Roman World. Ed. Tim Whitmarsh. Cambridge: Cambridge University Press, 2010. 1-16.

Wiater, Nicolas. The Ideology of Classicism. Language, History, and Identity in Dionysius of Halicarnassus. Berlin; New York: de Gruyter, 2011. 


\section{Onkraj primerjave? Učinki literarnega prisvajanja na poavgustovsko grško-rimsko besedilno produkcijo}

Ključne besede: starogrška književnost / rimski imperij / poavgustovska doba / recepcija / identiteta / literarno prisvajanje

Članek se osredotoča najprej na rimsko recepcijo zgodnje grške literature, ki ni bila preprosto "sprejemanje« tujega vpliva, temveč prej aktivno "prevzemanje» in dejanje prisvajanja, nato še na učinke, ki jih je imel ta proces na imperialno grško književnost. V ospredju je vprašanje, ali imamo lahko grško literaturo v imperialnem obdobju vsaj do neke mere za avtonomen, svetovljanski in policentričen pojav sam po sebi, z lastnim zagonom in neodvisnimi produkcijskimi centri, ki so oblikovali svojo lastno identiteto. Še drugače, ali naletimo v imperialni dobi (pa do drugega stoletja našega štetja) v literarnih besedilih na dominantno perspektivo, ki je prispevala h krepitvi in redefiniciji perspektive rimskega imperija ter identitete središča z vidika periferije. V članku obravnavana grška besedila navajajo k razlagi, da je poavgustovska doba kljub lokalni raznolikosti in večetničnosti monopolizirala lastno perspektivo. To je spodbudilo grško elito, da se pridruži imperialnemu projektu, in omogočilo nastanek grško-rimske literature, za katero se zdi, da je ni mogoče primerjati.

1.01 Izvirni znanstveni članek / Original scientific article

UDK 82.091

[821.124+821.14].09

DOI: https://doi.org/10.3986/pkn.v44.i2.02 